\title{
The Implementation of Gender Mainstreaming in ASEAN
}

\author{
Athiqah Nur Alami1
}

\begin{abstract}
Studies on gender mainstreaming in Southeast Asia, with its diverse socio-political background of its member states, are still under-explored. This paper examines the implementation of gender mainstreaming in the Association of Southeast Asian Nations (ASEAN). Meanwhile, the region has shown its considerable economic growth and rapid development of human rights issue in the last decades. The study finds that ASEAN has shown its initiatives across different stages of gender mainstreaming. By the adoption of gender mainstreaming concept, ASEAN has made institutionalization of gender issues and also has produced and implemented extensive gender mainstreaming policies. However, there are constraints on each stage, which mostly are about conforming gender equality agenda to organizational mandates as well as lacks of supporting systems such as data, human resources, and funding. Even though this paper agrees on the long-term nature of gender mainstreaming strategy, the implementation of the strategy in ASEAN should be effectively improved and consistently maintained to fulfill the goals of ASEAN Community
\end{abstract}

Keywords: Gender Mainstreaming, ASEAN, Gender Equality, ASEAN Community, Southeast Asia

\footnotetext{
1 The author is a researcher at the Centre for Politics, The Indonesian Institute of Sciences. She is currently finishing her doctoral project at the National University of Singapore. Corresponding e-mail: athiqah.nur.alami@gmail.com
} 


\section{Introduction}

"The spirit of promoting gender equality should be an integrated part of ASEAN'S policies and programmes towards the ASEAN Community. The goal of gender equality should be central to all three pillars of economy, political-security, and Socio-cultural of ASEAN" (H.E. Le Luong Minh, Secretary-General of ASEAN). ${ }^{2}$

During the last decade, the concept of gender mainstreaming has been developed and practiced in different countries and institutions in various contexts, which impacts its acceptance, implementation, and policy outcomes. This situation is inevitable, according to Hafner-Burton and Pollack (2000), because gender mainstreaming is a demanding strategy. It requires policymakers to adopt a different perspective, to learn new skills, and to change procedures in existing institutions. In institutional context, the implementation of gender mainstreaming can be seen in the establishment of a special unit to deal with gender issues, special programs to improve the condition of women, training to build capacity and gender sensitivity, and the development of analytical tools for gender mainstreaming through planning, monitoring, evaluation, and budgeting.

The practice of gender mainstreaming in institutions occurs in three stages: the adoption of gender equality or gender mainstreaming in organizational processes, the adoption of gender mainstreaming in institutional policies or programs, and the implementation of gender mainstreaming policies. Even though each stage has its own constraints, it can reflect gender mainstreaming practices. The tensions in these practices include the instrumentalization of gender issues, bureaucratic resistance, lack of capable and competent human resources, and the absence of monitoringevaluation mechanism.

In this paper, I examine the implementation of gender mainstreaming in the Association of Southeast Asian Nations (ASEAN) in these three stages. It questions where among these stages ASEAN's gender mainstreaming practices are. This study is important for several reasons. First, studies on the implementation of gender mainstreaming in Southeast Asia, and especially in ASEAN, remain limited, confirming Blackburn's claim that not many political scientists are interested in

\footnotetext{
2 This statement was part of the opening remarks of the Secretary-General of ASEAN at the Gender Mainstreaming Training in Jakarta on 13 February 2013.
} 
exploring the gender dimensions of social and political issues in Southeast Asia (Blackburn, 2009, p. 65). In fact, in recent years, Southeast Asia, including ASEAN, has shown considerable economic growth and development of human rights issues once relegated to the private sphere. The establishment of the ASEAN Community is also another interesting development issue that can be analyzed from gender perspectives. As indicated by the ASEAN Secretary-General's statement quoted above, the ASEAN Community, with its three pillars, should adopt gender issues as a concern due to its fundamental relevance to reaching the goals of the ASEAN Community.

Secondly, most studies on the practice of gender mainstreaming in institutions use the experiences of the European Union (EU), United Nations (UN) agencies such as UNDP and ILO, and international development institutions such as the World Bank and the Asian Development Bank (ADB), as case studies. This is somewhat understandable, since the EU, according to Hafner-Burton and Pollack (2009), is the international leader in the adoption of gender mainstreaming. UN agencies are also mentioned in the Beijing Platform for Action (BPfA) as stakeholders with the responsibility of implementing gender mainstreaming policies. Moreover, since the emergence of gender mainstreaming as a concept is closely linked to the issue of gender inequality in development, this policy also targets international development institutions.

As a consequence of these considerations, the implementation of gender mainstreaming in an Asian context, particularly Southeast Asia with all of its complexity, has not been widely explored. However, there have recently been some studies on gender issues in ASEAN, especially related to the Women, Peace, and Security agenda. For that purpose, the paper aims to examine the institutional practice of gender mainstreaming in ASEAN that includes two parts. First, it reviews the literature on the stages of gender mainstreaming practices in institutions. Second, the paper explores the implementation of gender mainstreaming in ASEAN, which serves to illustrate the implementation and constraints of gender mainstreaming. The article closes with its conclusion. 


\section{Gender Mainstreaming in Institutions: Conceptual Framework}

The BPfA (1995), as the output of the Fourth World Conference on Women, is the first document to emphasize explicitly the need for gender mainstreaming policies. It urges governments and other actors, including international organizations, to adopt gender mainstreaming policies as part of their strategic objectives and actions in twelve critical areas of concern. The document asserts that "Governments and other actors should promote an active and visible policy of mainstreaming a gender perspective into all policies and programs, so that, before decisions are taken, an analysis is made of the effects on women and men respectively." According to Moser and Moser (2005), the practice of gender mainstreaming, can be seen in three stages: adopting the terminology of gender equality and gender mainstreaming; putting gender mainstreaming policy into place, and implementing gender mainstreaming. These three stages are discussed in the following sections.

\section{Adopting Gender Equality and Gender Mainstreaming Concept}

The concept of gender mainstreaming has been considered a gender equality policy. The United Nations Economic and Social Council (UN ECOSOC) defines gender mainstreaming as:

The process of assessing the implication for women and men of any planned action, including legislation, policies or programs, in any area and at all levels. It is a strategy for making the concerns and experiences of women as well as men an integral part of the design, implementation, monitoring and evaluation of policies and programs in all political, economic and societal spheres so that women and men benefit equally, and inequality is not perpetuated.

However, arguably there is still no agreed definition of gender mainstreaming that impacts its varied implementation, and as such thus many scholars consider it a contested concept. In spite of that, this concept has been adopted in many institutions. The adoption of gender mainstreaming, in Prugl and Lustgarden's view, is part of an infusion of gender considerations into the organization process (Prugl \& Lutsgarten, 2006, p. 56).

One effort for adopting gender mainstreaming is through the establishment of special units or divisions in institutions that handle women's and gender issues. It shows that there is an institutionalization of gender issues. Some scholars recognize 
that gender mainstreaming is about the institutionalization of gender issues in development (Mukhopadhyay, 2014, p. 356). In the case of the World Bank, for example, as shown in Prugl and Lustgarden's study (2006), concern for women's issues was realized in the creation of an advisor on Women in Development (WID) in 1980. In 1990, the unit was replaced with a Gender Analysis and Policy Thematic Group. Likewise, EU support for gender issues was shown in 1995 with the formation of the Commissioners' Group on Equal Opportunities and the Commissioner for Employment and Social Affairs. A year later, the EU formed the Inter-Service Group on Gender Equality, which was put under the Commissioner's Group and the Unit for Equality between Women and Men, which replaced the Equal Opportunities Unit within the Directorate-General Employment and Social Affairs (Mazey, 2002, p. 233).

It appears that the policies of the World Bank and EU cannot be separated from development issues. First, international organizations were urged to adopt a Women in Development (WID) approach, which was replaced by the Gender and Development (GAD) approach in the 1990s. Policies, thus, were not actually based on analysis of gender inequality issue in society. In addition, the establishment of new units was unable to fully challenge existing policies, because this did not change or revise the existing organizational policies. However, acknowledging the long-term nature of gender mainstreaming, this paper agrees with Mahapatro (2014), who calls gender mainstreaming a "complex" and "sustainable continuous" process seeking to achieve gender mainstreaming in gender-blind policies.

Because gender mainstreaming is a process, other ways for adopting it are apparent in organizational processes such as capacity building. This aims to build awareness of gender issues in institutions, for example, by organizing gender training. This is necessary as there is a lack of knowledge and skill competencies on gender issues among policymakers and staff that potentially challenge the implementation of gender mainstreaming in institutions. Not everyone has knowledge regarding or sensitivity to gender issues. Gender training is expected by staff with have a commitment to gender issues (Moser \& Moser, 2005, p. 16), but they insist that training should be conducted not only at the junior level but also at the senior management level with consideration of gender focal points. Moreover, to overcome the lack of knowledge and skills among the staff, a number of 
organizations have chosen to employ what Mazey (2002) calls "flying gender experts", persons considered to have practical knowledge and experience with the issue.

\section{Mainstreaming Gender in Policies}

Once an institution has recognized the concept of gender mainstreaming and adopted it internally by establishing special units and through its capacity building, the next stage is creating gender mainstreaming policies. This is a stage where institutions mainstream policies or programs using a gender perspective. In other words, it is about integrating the concerns of women and men into organizations' policies or programs. According to Moser and Moser (2005), six key components can reflect gender mainstreaming in policies: gender mainstreaming; gender analysis; responsibility sharing between staff and gender experts; gender training; supporting women's empowerment and decision-making; knowledge resources; and monitoring and evaluation. They also developed indicators to assess each component of gender mainstreaming policies. For example, gender analysis includes the availability of sexdisaggregated data and gender budgeting; gender training involves producing manuals or toolkits; and the knowledge resources component may include publication of reports, joint networking, and production of online databases.

The practice of gender mainstreaming also can be seen in policies implying what Jahan calls an "integrationist approach" or "agenda-setting approach". The integrationist approach is a kind of add-on approach that incorporates gender or women agendas in policies, and it tends not to challenge the existing framework (1995, p. 13). Although this approach may be too focused on the bureaucratic process, Lombardo (2005) argues that it is powerful in its emphasis on the role of gender experts in policy formulation and its potential to create effective integration once gender mainstreaming is accepted by decision makers. Therefore, in the context of the EU, Lombardo (2005) argues that the integrationist approach has succeeded in formally introducing gender mainstreaming in EU policies, but did not bring effective implementation at the policy-making level.

Meanwhile, the agenda-setting approach entails a paradigm shift in existing policy and generates entirely new concepts of gender mainstreaming. It is also intended to reform or reorient established global governance frameworks. According 
to Lombardo (2005), it implies a transformation and reorientation of existing policy paradigms by changing decision-making structures and processes, prioritizing gender objectives among competing issues, and reorienting the mainstream political agenda by rethinking and rearticulating policy ends and means from a gender perspective. He also affirms the recognition of women's voices via consultation processes is one of the strengths of this approach (Lombardo, 2005, p. 415).

However, in the mainstreaming of gender policies, there is a potential problem of instrumentalism, where gender mainstreaming - as a gender equality policy - is developed as a means of development, rather than as an end (Moser \& Moser, 2005, p. 14). Gender mainstreaming policy is formulated in a particular organization's context with its specific pressures, mandate, and ideology; as such, an organization's gender policy and mandate must 'fit' (Razavi, 1997). Proponents of instrumentalism argue that the situation is unavoidable because there is an existing organizational context and paradigm, and that is where the logic of gender mainstreaming should play. Moreover, in real politics, compromises and strategic alliances are a reality that must be faced.

Meanwhile, opponents of instrumentalism claim that it is risky to depoliticize the transformative nature of the feminist agenda. This will potentially create problems when there is conflict between gender policy and other issues (Moser \& Moser, 2005, p. 15). As stated by Allwood (2014, p. 16), for example, when policy issues intersect with gender, gender disappears. It is because, in the case of the EU, the highly sectoral policy-making structures make it difficult to gender mainstream cross-cutting issues such as climate change. As a result, to negotiate with this technocratic policy style, according to Mazey (2002), the EU has largely adopted the 'dominant' Nordic, top-down, expert-bureaucratic model of gender mainstreaming. In addition, gender advocates strategically have to frame gender mainstreaming to make it fit within the dominant frame to avoid potential resistance (Hafner-Burton \& Pollack, 2009, pp. 452-453). Instrumentalism also may lead to a co-optation by other agendas. According to True and Parisi (2013), the intersection of gender mainstreaming approaches that focus on the World Bank's processes and neo-liberal agenda, for example, makes gender agenda co-opted by an economic growth agenda.

Among the above two forms of gender mainstreaming policies, feminists actually have the ambition to realize the agenda-setting approach of gender 
mainstreaming policies (Walby, 2005, p. 324). However, in practice, gender mainstreaming policies are still likely to adapt an integrationist model. The trend can be seen in the findings of a number of studies, which show that most international organizations prefer to integrate women and gender issues within specific policies, rather than challenging the organizations' main goals (Razavi and Miller 2005; Rees, 2005). Lambardo's study on the EU's Convention II constitution-making process shows that gender mainstreaming was integrated, but did not change the orientation of the constitution-making process (Lombardo, 2005, p. 427). Despite the character of the constitution-making process in democratic Europe, the convention still maintained patriarchal elements often seen in various contexts.

The same trend is also visible in gender mainstreaming in gender and security issues. In theory, UNSCR 1325 is intended to involve various actors to facilitate an agenda-setting model, but Barrow (2009) claims that empirical data show that women's involvement in peace and security processes still follow the integrationist model, which ultimately stops at "redressing gender-blind peace and security processes" (Barrow, 2009, p. 66). The above findings confirm Razavi and Miller's (1995) study on the UNDP, World Bank, and ILO, which concludes that, in general, international organizations adopt an integrationist approach in gender mainstreaming by integrating women and gender issues into specific policies rather than thinking about organizations' fundamental goals from a gender perspective (Razavi \& Miller, 1995, p. 66). Based on these experiences, it appears that the integrationist model does not question existing policy paradigms or is considered less substantial. However, the adoption of the integrationist model requires more effort too. Gender advocates in institutions must think strategically about how to keep the gender agenda and fit it into their organization's culture.

\section{Implementing Gender Mainstreaming}

The last stage of gender mainstreaming strategy is implementation, where the challenges are apparent in most of their practices in institutions. Moser and Moser (2005) explain that gender mainstreaming implementation can be seen in two aspects: institutional and operational implementation. At the institutional level, implementation means the practice of gender mainstreaming in organizational 
culture and procedures. It is usually in the form of shared responsibilities among organizational staff and capacity building programs.

Meanwhile, the operational level is about addressing operational outcomes and impact on gender mainstreaming. One way to handle the operational gender mainstreaming implementation is by cooperating and collaborating with civil society in gender mainstreaming policy. This works well on the issue of Women, Peace, and Security. The establishment of a regional action plan for implementing UNSCR 1325 by the Pacific Islands Forum, for example, is a shining example of cooperation individual women's organizations, assisted by regional UN agencies (UN Development Program Pacific and UN Women Pacific) and bilateral aid agencies (such as the Australian Agency for International Development). George (2016, p. 376) refers to them as the key drivers of this policy framework.

However, implementing gender mainstreaming has met several types of resistance, mostly at the institutional level. Bureaucratic resistance is one constraint on implementing gender mainstreaming in an institution. Rao and Kelleher's study (2005) finds a deep-seated and entrenched resistance to gender transformation in the development of many organizations. A review of gender mainstreaming in nine international development agencies by Aasen (2006) also finds that widespread resistance existed towards gender equality programs in the 1990s. Additionally, a study by True and Parisi (2013) reveals the emergence of resistance in the implementation of gender mainstreaming in institutions, not only because it is too confusing or too threatening, but also because of policy-makers' lack of understanding of gender perspective's substantial significance to policy issues. According to Moser and Moser (2005), male resistance and non-committed decision makers do not support gender issues that should be their responsibilities, and as a result specialized gender focal points are marginalized in mainstream activities. This condition confirms True and Parisi's finding that bureaucratic processes exclude women's movements (True \& Parisi, 2013, p. 47).

Moreover, in implementing gender mainstreaming policy, institutions share responsibilities among staff and gain support from gender specialists. However, according to Moser and Moser (2005), the success of implementing gender mainstreaming depends not only on the commitment and skills of key individuals but also on support from senior staff (ADB, 2012, p. 12) and organizational culture. 
How can an organizational culture that is male-biased in its behavior, recruitment, and working conditions, and that discriminates against female staff and clients, support gender mainstreaming policy? As a result, staff become desperate because gender mainstreaming is not achieved in their organizations (Moser \& Moser, 2005, p. 16). In other words, according to Parpart (2014), hostile institutional culture and skeptical leadership undermine the implementation of many gender mainstreaming programs in major development institutions.

Another important issue in the implementation stage is the absence of monitoring and evaluation, both at the institutional and at the national level. This mechanism is indeed significant to assess the success or failure of gender mainstreaming policies. Since gender is deployed in various ways by different international organizations according to their institutional mandates (True and Parisi, 2013, p. 44), it may produce diverse results. The mechanism is also valuable as part of accountability in gender mainstreaming policies with specific targets, funding, and coordination with various partner institutions.

Assessing the impact of gender mainstreaming practice is important in the implementation stage. However, gender mainstreaming in implementation has not yet considered being transformative in changing existing policy to be gendersensitive and achieve gender equality. Although Hafner-Burton and Pollack (2009) argue that gender mainstreaming is about inserting gender-equality perspective into all levels of 'mainstream' public policy, its implementation still faces numerous challenges. One challenge is the potential loss of feminist political objectives in the institutional mainstreaming process (Milward et al., 2015, p. 75). Therefore, ensuring the accomplishment of gender equality goals in implementing gender mainstreaming policies requires greater effort and commitment from all stakeholders.

\section{Implementing Gender Mainstreaming in ASEAN}

As part of the international community, ASEAN is also responsible for participating and supporting the global gender agenda to eliminate gender inequalities through gender mainstreaming policies. Although ASEAN, established in 1967, has been considered the world's oldest regional organization, it has shown a number of positive developments in the past two decades. Economically, since 2007, 
the annual average economic growth of ASEAN member countries has reached $5.1 \%$, higher than the average growth of the global economy (Jha \& Saxena, 2016, p. 9). In addition, the World Economic Forum (2014) noted that ASEAN member countries have experienced $30.7 \%$ global progress in reducing the gender gap compared to $2013(31.1 \%)$.

Table 1. ASEAN's Initiative on Women and Gender Issues

\begin{tabular}{|c|c|c|}
\hline No. & $\begin{array}{c}\text { Year of } \\
\text { Establishment }\end{array}$ & Initiatives of Policies \\
\hline 1. & 1975 & Convening of the ASEAN Women Leaders Conference \\
\hline 2. & 1976 & Establishment of ASEAN Sub-Committee on Women (ASW). \\
\hline 3. & 1981 & ASW Renamed ASEAN Women's Programme (AWP) \\
\hline 4. & 1988 & $\begin{array}{l}\text { Adoption of the Declaration of the Advancement of Women, } \\
\text { operationalised in the Work Plan for Women's Advancement and } \\
\text { Gender Equality (2005-2010) }\end{array}$ \\
\hline 5. & 2002 & AWP Reformed as the ASEAN Committee on Women (ACW) \\
\hline 6. & 2002 & Establishment of ASEAN Ministerial Meeting on Women (AMMW) \\
\hline 7. & 2004 & $\begin{array}{l}\text { Adoption of the Declaration on the Elimination of Violence } \\
\text { against Women, operationalised in the Declaration on the } \\
\text { Elimination of Violence against Women (2006-2010) }\end{array}$ \\
\hline 8. & 2004 & $\begin{array}{l}\text { Adoption of the ASEAN Declaration Against Trafficking in } \\
\text { Persons Particularly Women and Children (DATP) }\end{array}$ \\
\hline 9. & 2007 & $\begin{array}{l}\text { Adoption of the ASEAN Declaration on the Protection and } \\
\text { Promotion of the Rights of Migrant Workers (ADRMW), followed } \\
\text { by the establishment of the ASEAN Committee on the } \\
\text { Implementation of the Declaration on the Protection and } \\
\text { Promotion of the Rights of Migrant Workers (2008) }\end{array}$ \\
\hline 10. & 2010 & $\begin{array}{l}\text { Establishment of the ASEAN Commission on Women and } \\
\text { Children (ACWC) }\end{array}$ \\
\hline 11. & 2010 & $\begin{array}{l}\text { Adoption of the Hanoi Declaration on the Enhancement of } \\
\text { Welfare and Development of ASEAN Women and Children } \\
\text { (DEWD) }\end{array}$ \\
\hline 12. & 2012 & $\begin{array}{l}\text { Convening of the First ASEAN Ministerial Meeting on Women } \\
\text { (AMMW) }\end{array}$ \\
\hline 13. & 2013 & $\begin{array}{l}\text { Adoption of the Declaration on the Elimination of Violence } \\
\text { against Women and Elimination of Violence against Children in } \\
\text { ASEAN (DEVAW and VAC) }\end{array}$ \\
\hline 14. & 2015 & $\begin{array}{l}\text { Convening of the Second ASEAN Ministerial Meeting on Women } \\
\text { (AMMW) }\end{array}$ \\
\hline
\end{tabular}

(Source: Davies, 2016, pp. 109-110)

Meanwhile, in the institutional context, ASEAN has taken a new direction in realizing its vision as a caring and sharing community under the ASEAN Community with three pillars: ASEAN Political-Security Community, ASEAN Economic 
Community, and ASEAN Socio-Cultural Community. ASEAN also frequently brings together non-governmental organizations and civil society organizations to participate actively in various consultation processes regarding a number of issues, including gender issues. In addition, the principles of human rights have been introduced and embodied in three human rights bodies, namely the ASEAN Intergovernmental Commission on Human Rights (AICHR), the ASEAN Commission on the Promotion and Protection of Women and Children's Rights (ACWC), and the ASEAN Declaration on the Protection and Promotion of the Rights of Migrant Workers (ACMW). As assessed by Mohamad (2002), the proliferation of these human rights and democracy discourses in the region have been modest progress since the Asian financial crisis of 1997.

There are positive developments in ASEAN's initiatives regarding gender and women's issues, as seen in Table 1, from ASEAN's early involvement in women issues through the convening of the ASEAN Women Leaders Conference in 1975, to the latest ASEAN Ministerial Meeting on Women. These various initiatives show that ASEAN has adopted gender issues in policy by addressing several problems in the region, such as violence against women and children as well migrant workers. However, the question is at what stage ASEAN's gender mainstreaming has been implemented. The answer to this question will be reflected in the general practice of gender mainstreaming in ASEAN.

\section{Adoption of Gender Mainstreaming in ASEAN's Organizational Processes}

Gender mainstreaming, here, is understood as focusing on infusing gender considerations into organizational processes. In the context of ASEAN, the first step in the process is the conceptual adoption of gender equality in the institution. Although ASEAN does not provide a specific definition of gender equality, referring to the Asia-Pacific Human Development Report in the ACW Work Plan (2011-2015), it agrees that gender equality is about equipping women and men with equal access and capacity so they have freedom to choose opportunities and improve their lives. Because all people are inherently valuable, gender issues need to be taken into account in policies, plan, and programs.

Moreover, ASEAN outlines several conceptual elements that have become the overall framework approach for implementing gender issues: "walking on two legs", 
meaning to intensify protection of women against all forms of violence but also promote women's rights and gender analysis in other areas; "strengthening gender perspectives and analysis", decidedly moving beyond the "add women and stir" approach and the "ghettoization of women", and pursuing the complementation and integration of gender analysis and goals with other work programs and committed actions; expanding the reach of gender mainstreaming by moving decidedly beyond the "traditional women's issues" and "women's comfort zones" and applying a more vigorous gender lens to a variety of political, economic and social issues (ASEAN Secretariat 2012, pp. 13-14). It shows that ASEAN actually has a firm understanding of the importance of applying gender perspectives and adopting gender mainstreaming in its policies.

This commitment is evident from the establishment of special units working on gender issues within ASEAN. At least three bodies have been established for gender mainstreaming, namely, the ASEAN Committee on Women (ASW), a sectoral body; the ASEAN Commission on Women and Children (ACWC), an ASEAN human rights instrument that specifically focuses on women and children; and the ASEAN Ministerial Meeting on Women (AMMW) which is located under the Social-Cultural Community pillar.

Besides establishing organizational special units, the internalization of gender perspectives among internal actors is significantly needed. In an attempt to improve the capacity building of its staff as part of its organizational processes, ASEAN affirms its commitment. For instance, the ASEAN Secretariat held a Gender Mainstreaming Training session in 2013 intended to enhance knowledge on gender mainstreaming elements, approaches, and strategies to assist staff in gaining practical skills for measuring organizational capacity to address gender issues and mainstream gender perspectives in their respective lines of work. Over eighty ASEAN secretariat staff members joined the training. H.E. Alicia R. Bala, Deputy Secretary-General for the ASEAN Socio-Cultural Community (ASCC), highlighted that "The role of the ASEAN Secretariat is critical in making gender mainstreaming as a standard practice in ASEAN's policies and programs across the three pillars" (ASEAN Secretariat News, 2013). She then argued that, before we are able to effectively stimulate gender mainstreaming strategy in ASEAN, we first need to understand clearly the concept of gender equality and how gender mainstreaming strategy can be applied in our work. 
However, the adoption of gender mainstreaming in institutionalization poses several challenges. The specific bodies that handle women's issues have limitations in the nature of their mandates or positions. The weakness in the institutionalization of gender issues in ASEAN has emerged since the convening of the ASEAN Women Leaders Conference, which was perceived to be elitist because it only involved women leaders that were non-political and did not threaten the status quo (Davies, 2013 , p. 52). Also, even though its members were senior officials, ACW's position outside of ASEAN's organizational structure meant it was considered not part of ASEAN. This sectoral body also had many responsibilities, such as promoting the implementation of effective programs and cooperation on women issues, preparing regional reports, and collaborating with other internal and external actors in ASEAN. In the recent work plan, ACWC has also been given the responsibility to influence all pillars and thereby produce a visible, credible, and strong input for governments. Could these huge responsibilities possibly be handled by one "outsider" unit? ACWC's status as an intergovernmental body is also criticized for its independence since its members are government representatives.

Moreover, AMMW's position under the ASEAN social-cultural community pillar (instead of the other two pillars) is questioned. Proponents argue that locating women's issues in a particular body will draw more focus on policies and make it easier to monitor. In contrast, questions emerge as to whether it indicates that women's (and gender) issues seem to only be discussed from a socio-cultural perspective rather than a political security or economic perspective. The position of women's issues under the socio-cultural community pillar means only that a gender perspective has not been effectively mainstreamed in all pillars. This has been identified as one problem in the October 2015 progress report on women's rights and gender equality in ASEAN (Dios, 2016). This shows that gender issues still experience challenges as related to political security issues, including in the recognition of the role of women in conflict resolution and peacebuilding. From an economic perspective, the problem lies in the lack of recognition of women's contributions to economic growth and development, particularly in the informal sector (Jha \& Saxena, 2016). The contribution of women in political-security and economic issues are indeed relevant and must be recognized. 
Also, putting women's concerns under the ACWC implies that women's issues must be a separate commission, rather than being integrated into the AICHR. It suggests that their issues are different in status than other human rights concerns (Davies et al., 2014, p. 420). It seems that ASEAN's reluctance to incorporate women's issues into the political security pillar is indicated by its slow progress in following up the Women, Peace and Security agenda (particularly relative to its response to development issues). In fact, Davies et al., (2014) argue that most ASEAN member states are vulnerable to conflict and experiences in these countries show the magnitude of the role of women in conflict situations, especially in conflict resolution. During the conflict and peace settlement process in Aceh, Indonesia, for example, some Acehnese women played roles as combatants, arms smugglers, mediators, and peace lobbyists. Likewise, women's presence in the conflict in Kachin, Myanmar, was apparent since they participated as soldiers or military-trained members of the civilian administration of the Kachin Independence Organization (International IDEA 2015, p. 62). Therefore, a gender and security agenda is arguably relevant for ASEAN member states. The above situation is considered ironic, since gender equality has become the accepted norm in ASEAN countries and institutionalized through the ratification of CEDAW and CRC, both of which are the only UN treaties to be ratified by all ten ASEAN member states. This contrasts with ASEAN leaders' commitment that gender issues should be a central part of the third pillar of ASEAN community.

\section{ASEAN's Gender Mainstreaming Policies}

The second stage of gender mainstreaming is at the policy level. In general, ASEAN has produced several work plans to operationalize and guide the implementation of the mandates of the ACW, the ACWC, and the AMMW on issues of women and gender. Since one of its mandates is to monitor and evaluate the implementation of a women and gender agenda, the ACW sets up policies for monitoring and evaluating the effectiveness of undertaken projects or activities. It includes mid-term reviews, final reviews, and reports of work plan implementation.

As part of its gender training, the ACWC has policies to develop guidelines to take a non-violent approach to women's issues and avoid gender stereotyping in curriculum and textbook writing for higher education. To strengthen the 
institutional capacity of the ACWC, it holds fundraising activities. Moreover, to gain knowledge resources, it has established the ACWC Network of Social Service Agencies (NOSSA) to promote consultation and dialogue with stakeholders at the national and regional level, as well as a public campaign to stop violence against women. To apply a gender perspective in policies, strategies, and programs for migrant workers, there is also high-level consultation on gender perspectives in policies, strategies, and programs for migrant workers, including experts and relevant policy makers.

The practice of gender mainstreaming in ASEAN shows that the organization has adopted an integrationist approach, rather than agenda-setting. The existence of women-only units or policies in ASEAN, for example, shows that its organizational logic has not switched from the long-abandoned WID approach. The GAD logic that focuses on gender relations between men and women in public policies does not seem to underlie ASEAN's gender mainstreaming policies.

In addition, ASEAN's integrationist policies in gender mainstreaming are not intended to challenge or change existing organizational paradigms. The main foundations of ASEAN policy - the 1967 ASEAN Declaration, the 1976 Treaty of Amity and Cooperation (TAC) in Southeast Asia, and the ASEAN Charter - are almost untouchable in attempts to apply gender perspectives in the existing rules of the game. These documents still adopt gender-neutral or gender-blind language that is male-centered (Prasertri et al., 2014, p. 17). This means that ASEAN's fundamental principles of sovereignty, non-use of force, peaceful settlement of disputes, noninterference, and consensus in decision-making processes that lie at the heart of "ASEAN ways" makes it impossible to criticize member states' policies that violate the human rights of women and children.

As such, ASEAN contributing to addressing the four main gender issues in the region - economic participation of women, migration and discriminatory laws, political participation, and violence against women (Al-Ghozaly, 2012) - remains a distant hope.

\section{Implementing Gender Mainstreaming in ASEAN}

ASEAN has produced many policies related to gender issues. No less important is the implementation of these policies, both at the institutional level and the 
operational level. Operationally, there has been significant progress in addressing the issue of violence against women through concerted efforts at regional and national level. ASEAN member states have produced National Action Plans (NAP) to support the implementation of laws and policies addressing violence against women and children. In 2009, the Philippines launched a NAP for the 2010-2016 period for implementing UNSCR 1325 and 1820 in response to various forms of violence against women during conflicts. The Indonesian government also launched its first NAP in 7 March 2014, titled National Action Plans for the Protection and Empowerment of Women and Children during Social Conflict (2014-2019) (RAN P3A-KS), through Presidential Decree No. 18 of 2014. ACWC also developed the Gender Sensitive Guidelines for Handling Women Victims of Trafficking in Person, convened the Regional Workshop on Promoting the Right to a Nationality for Women and Children in the Implementation of CEDAW and CRC in ASEAN, and conducted a public campaign to stop violence against women. In this, they have also cooperated and collaborated with civil society.

However, there are still some challenges to its implementation. The ASEAN Regional Action Plan of Action on the Elimination of Violence against Women report (2015) notes that the progress of addressing violence against women has been uneven. For example, marital rape and other forms of sexual violence have not been covered fully in the legislations of all ASEAN member states. Cambodia's Law on the Prevention of Violence and the Protection of Victims in 2005, for instance, does not cover marital rape. The 1994 Domestic Violence Act in Malaysia is the same. Meanwhile, Thailand's Protection of Domestic Violence Victims Act B.E. 2550 (2007) includes marital rape, as is the case of Vietnam's Law on Prevention of and Control over Domestic Violence (2007). This issue still requires that data gaps on the extent and impact of violence against women be given attention, as well as support for human resources and funding law enforcement/delivery of support services.

According to the 2011-2015 ACW Work Plan (2012), the availability of sexdisaggregated data has been another obstacle in the implementation of gender policy in ASEAN. Sex-disaggregated data is crucial for evidence-informed policy-making, monitoring, and reporting of gender equality commitments. There are differences on what data ASEAN member states measure, and traditional indicators of the gender gap and unpaid work do not exist. This obstacle occurs not only at the national level, 
but also at the ASEAN level. Data on the implementation of policies on women's rights and gender equality has not been regularly collected and presented, and as a result ASEAN depends more on the reliable data provided by other international organizations such as the World Bank, ADB, and UNESCAP. Another constraint of gender mainstreaming in ASEAN, as noted by ACW in its 2011-2015 Work Plan, is the persistent resistance to and inadequacies in understanding how gender power relations and rooted attitudes and perceptions of women and men operate to subordinate and discriminate against women.

In the case of ASEAN's adoption of CEDAW, studies by Li-ann, Linton, and Davies (as quoted by Davies, 2016, p. 111) find that there is still a considerable gap between the commitments made by member states and the achievement of rights within their domestic political contexts. ASEAN's member states still put reservations on CEDAW in different issues. Singapore, for example, made articlespecific reservations (Article 2 on Policy Measures; Article 9(2) on Nationality; Article 11 on Employment; and Article 16 on Marriage and Family Life), as did Malaysia with Article 5(a) on Role Stereotyping and Prejudice and Article 7(b) on Political and Public Life and Brunei Darussalam with Article 9(2) on Nationality. The ACWC, whose mandate is to encourage member states to complete the ratification of relevant international human rights instruments on women and children, including CEDAW, has been unable to pressure them. In response, Linton (2008) argues that reservations toward human rights treaties are not about ASEAN values or Asian values, but about particular circumstances in member states' and their societies, such as the prevailing attitudes about women and the role of culture and religion.

These situations confirm some constraints of gender mainstreaming implementation that have been identified in most international organizations, particularly the lack of resources (i.e. reliable data, capable human resources, and sustained funding). Hence, ASEAN has not seen much progress in implementing the policies that have been generated.

\section{Conclusion}

To summarize, ASEAN has shown considerable progress in initiatives related to women and gender issues. In its adoption of conceptual approaches to gender equality and gender mainstreaming, ASEAN still needs to clarify its own definition of 
the concepts instead of borrowing definitions from other institutions. However, ASEAN has progressed in institutionalizing gender issues by setting up special bodies to handle these issues. It has also begun building internal capacity to deal with gender issues.

Moreover, at the policy level the achievement of gender mainstreaming is evident. ASEAN has produced Work Plans to operationalize and guide its establishment and mandating of ACW, ACWC and AMMW. It also has extensive policies related to establishing gender training, optimizing knowledge resources, and gaining cooperation and collaboration with civil societies.

As in many institutions, challenges are mostly in the implementation of gender mainstreaming policies. Compared to the operational level, implementation at the institutional level has not gained much attention. It means that policies for improving organizational culture and procedures have not settled. In some cases, for example in CEDAW, the implementation of ASEAN's policy reflects more an obligation rather than a commitment. According to Benschop and Verloo (2006), the question is whether such obligation is enough to ensure that the gender analysis of policy is done well, or whether commitment is the key success. They argue that commitment may go hand in hand with obligation. Although Eveline and Bacchi (2009) agree, they argue that "commitment may follow from obligation" and suggest that commitments towards gender analysis in institutions will only be sustained if these institutions can see gender's relevance to their work.

Drawing from this argument, it must be considered whether ASEAN is the right and relevant forum for gender mainstreaming policies and for the achievement of gender equality objectives. If it is, how should ASEAN recognize the adoption of women and gender issues as more than merely fulfilling obligations, but also a commitment to achieving a caring and sharing ASEAN community. Also, despite progress in implementing gender mainstreaming policies, several fundamental constraints related to the availability of reliable data as well as human and funding resources should still be addressed by ASEAN.

The practice of gender mainstreaming in ASEAN, therefore, should mean more than adding women to existing policies and programs. Ideally, it should also change the organizational processes in ASEAN that can lead to changes in policy outcomes. 
Without gender-sensitive and people-oriented policy frameworks and practices, a caring and sharing ASEAN Community is impossible to achieve.

\section{References}

Aasen, B. (2006). Lessons from Evaluations of Women and Gender Equality in Development Cooperation. Oslo: Norwegian Institute for Urban and Regional Research.

African Development Bank (ADB). (2012). Mainstreaming Gender Equality: Operations Evaluation Department. Tunisia: African Development Bank.

Al-Ghozaly, M. N. (2012, 4 December) Whither Women's Rights in ASEAN? The Jakarta Post.

Allwood, G. (2014). Gender Mainstreaming and EU Climate Change Policy, in The Persistent Invisibility of Gender in EU Policy, ed. Elaine Weiner and Heather MacRae, European Integration Online Papers (EioP), Special Issue 1, 18, 6, http://eiop.or.at/eiop/texte/2014-006a.htm, 1-26.

ASEAN Secretariat News. (2013, 23 February). ASEAN SG: Gender Equality should be Central in Achieving ASEAN Community. Retrieved from http://asean.org/asean-sg-gender-equality-should-be-central-in-achievingasean-community/(8 August 2016).

ASEAN Secretariat. (2015). ASEAN Regional Action Plan of Action on the Elimination of Violence against Women (ASEAN RPA on EVAW). Jakarta: ASEAN Secretariat. . (2013). ASEAN Commission on the Promotion and Protection of the Rights of Women and Children: Work Plan 2012-2016 and Terms of Reference. Jakarta: ASEAN Secretariat.

(2012). ASEAN Committee on Women (ACW) Work Plan (2011-2015). Jakarta: ASEAN Secretariat.

Barrow, A. (2009). [It's] like a rubber band: Assessing UNSCR 1325 as a Gender Mainstreaming Process. International Journal of Law in Context, 5, 1, 51-68.

Beijing Declaration and Platform for Action, 15 September 1995.

Benschop, Y., \& M. Verloo. (2006) Sisyphus' Sisters: Can Gender Mainstreaming Escape the Genderedness of Organizations? Journal of Gender Studies, 15, 1, 2006, 19-33.

Blackburn, S. (2009). Has Gender Analysis Been Mainstreamed in the Study of 
Southeast Asian Politics, in Gender Trends in Southeast Asia: Women Now, Women in the Future, ed. Theresa W. Devasahayam. Singapore: ISEAS.

Council of Europe. (1998). Gender Mainstreaming: Conceptual Framework, Methodology and Presentation of Good Practices: Final Report of Activities of the Group of Specialists on Mainstreaming. Strasbourg: Council of Europe.

Davies, M. (2016). Women and Development, Not Gender and Politics: Explaining ASEAN's Failure to Engage with the Women, Peace and Security Agenda. Contemporary Southeast Asia 38, 1, 106-127. et al. (2014). States of Compliance? Global Human Rights Treaties and the ASEAN Member States. Journal of Human Rights, 13, 4, 414-433. . (2013). The ASEAN Synthesis: Human Rights, Non-Intervention, and the ASEAN Human Rights Declaration. Georgetown Journal of International Affairs, $14,2,51-58$.

Davies, S.E., K. Nackers., \& S. Teitt. (2014). Women, Peace, and Security as an ASEAN Priority. Australian Journal of International Affairs, 68, 3, 333-355.

De Dios, A.J. (2016). ASEAN Initiatives to Promote Gender Equality, 2016, Retrieved from http://www.ched.gov.ph/wpcontent/uploads/2016/01/6.1_ASEANInitiatives-AJDEDIOS.pdf (19 October 2016).

Eveline, J., \& C. Bacchi. (2009). Obeying Organizational 'Rules of Relevance': Gender Analysis of Policy. Journal of Management and Organization, 15, 5, 556-581.

George, N. (2016). Institutionalising Women, Peace and Security in the Pacific Islands: Gendering the 'Architecture of Entitlements'? International Political Science Review, 37, 3, 375-389.

Hafner-Burton, E. and M.A. Pollack. (2009). Mainstreaming Gender in the European Union: Getting the Incentives Right. Comparative European Politics, 7, 114-138. International Institute for Democracy and Electoral Assistance (International IDEA). (2015). Women in Conflict and Peace. Sweden: International Institute for Democracy and Electoral Assistance.

Jha, S., \& A. Saxena. (2016). Projected Gender Impact of the ASEAN Economic Community. Jakarta: The ASEAN Secretariat.

Linton, S. (2008). ASEAN States, Their Reservations to Human Rights Treaties and the Proposed ASEAN Commission on Women and Children. Human Rights 
Quarterly, 30, 436-493.

Lombardo, E. (2005). Integrating or Setting the Agenda? Gender Mainstreaming in the European Constitution-Making Process. Social Politics: International Studies in Gender, State, and Society, 12, 3, 412-432.

Mahapatro, M. (2014). Mainstreaming Gender: Shift from Advocacy to Policy. Vision, 18, 4, 309-315.

Mazey, S. (2002). Gender Mainstreaming Strategies in the EU: Delivering on an Agenda. Feminist Legal Studies, 10, 2002, 227-240.

Milward, K., et al. (2015). Gender Mainstreaming Critiques: Signposts or Dead Ends? IDS Bulletin, 46, 4, 75-81.

Mohamad, M. (2002). Towards a Human Rights Regime in Southeast Asia: Charting the Course of State Commitment. Contemporary Southeast Asia, 24, 2, 230-251.

Moser, C., \& A. Moser. (2005). Gender Mainstreaming since Beijing: A Review of Success and Limitations in International Institutions, Gender \& Development, $13,2,11-22$.

Mukhopadhyay, M. (2014). Mainstreaming Gender or Reconstituting the Mainstream? Gender Knowledge in Development. Journal of International Development, 26, 356-367.

Parpart, J.L. (2014). Exploring the Transformative Potential of Gender Mainstreaming in International Development Institutions. Journal of International Development, 26, 382-395.

Prasertri, D., et al. (2014). An ASEAN Handbook for Women's Rights Activist. Chiang Mai: Southeast Asia Women's Caucus on Women.

Prugl, E., \& A. Lustgarten. (2006). Mainstreaming Gender in International Organizations, in Women and Gender Equity in Development Theory and Practice: Institutions, Resources, and Mobilization, ed. Jane S. Jaquette and Gale Summerfield. Durham, NC, and London: Duke University Press.

Rao, A., \& D. Kelleher. (2005). Is There Life After Gender Mainstreaming? Gender \& Development, 13, 2, 57-69.

Razavi, S. (1997). Fitting Gender into Development Institutions, World Development, $25,7,1111-1125$.

Razavi, S., \& C. Miller. (1995). Gender Mainstreaming: A Study of Efforts by the UNDP, the World Bank, and the ILO to Institutionalize Gender Issues. UNRISD 
Occasional Paper 4.

Statement of Secretary-General of ASEAN at the Gender Mainstreaming Training in Jakarta on 13 February 2013.

True, J., \& L. Parisi. (2013). Gender Mainstreaming Strategies in International Governance, in Feminist Strategies in International Governance, ed. Gulay Caglar, Elisabeth Prugl, and Susanne Zwingel. London: Routledge.

United Nations. (1997). Report of the Economic and Social Council for 1997, A/52/3, 18 September 1997.

Walby, S. (2005). Gender Mainstreaming: Productive Tensions in Theory and Practice. Oxford University Press.

World Economic Forum. (2014). The Global Gender Gap Report 2014. Geneva: World Economic Forum. 